\title{
Evolution of diabetes mellitus in a case of Friedreich's ataxia
}

\author{
B. I. JOFFE, I. SEGAL, AND W. COOPER \\ From the Department of Medicine, University of the Witwatersrand Medical School \\ and Coronation Hospital, Johannesburg, South Africa
}

SUMMARY A 12 year old girl with Friedreich's ataxia, in whom progression from chemical to severe insulin-dependent diabetes mellitus occurred over a two year period, is presented. During the phase of subclinical diabetes her plasma immunoreactive insulin response to oral glucose was markedly increased, but when she became symptomatic gross insulin deficiency had supervened. This report draws attention to the unusual disorders of carbohydrate metabolism and insulin secretion that may occur in a variety of neurological conditions.

Although the development of diabetes mellitus in patients with Friedreich's ataxia (FA) is well described (Hewer and Robinson, 1968; Podolsky and Sheremata, 1970), the connection between the two diseases remains obscure. The diabetic state in FA may, early on, resemble that seen in ataxia telangiectasia, where carbohydrate intolerance is accompanied by marked hyperinsulinaemia (Joffe, Segal, and Keller, 1970; Schalch, McFarlin, and Barlow, 1970). We have followed a patient with FA in whom progression from chemical to severe insulin-dependent diabetes occurred over a two year period.

\section{CASE REPORT}

B.T., a 12 year old coloured girl, was noted to be ataxic at the age of 8 years. She was the youngest of six sisters, two of whom already had established FA when she was born. There was no family history of diabetes mellitus. By the time B.T. was 10 years old, she, too, was noted to have classical features of the disease. Well-marked limb incoordination, tendor hyporeflexia, posterior column sensory loss, bilatera pes cavus, and electrocardiographic abnormalities were all detected. Despite this, she retained full mobility. Renal and hepatic function was normal.

The results of a $50 \mathrm{~g}$ oral glucose tolerance tes done at that stage (27 September 1969) are shown in the Table; as seen, chemical diabetes was associated with marked hypersecretion of insulin-measured by the radioimmunoassay technique of Hales and Randle (1963). The patient was not obese $(80 \%$ of average body weight for height) and received an adequate carbohydrate intake before the study. Her two affected elder sisters, similarly investigated at the same time, showed normal glucose and insulin responses. No specific antidiabetic treatment was prescribed.

TABLE

PLASMA GLUCOSE AND INSULIN LEVELS DURING ORAL GLUCOSE TOLERANCE TESTS

\begin{tabular}{|c|c|c|c|c|c|c|c|c|c|c|}
\hline & \multicolumn{5}{|c|}{ Plasma glucose $(\mathrm{mg} / 100 \mathrm{ml})}$. & \multicolumn{5}{|c|}{ Plasma insulin $(\mu U / m l)}$. \\
\hline & $0 \min$ & $30 \min$ & $60 \min$ & $90 \min$ & $120 \min$ & $0 \min$ & $30 \mathrm{~min}$ & $60 \min$ & $90 \mathrm{~min}$ & $120 \mathrm{~min}$ \\
\hline $\begin{array}{l}27 \text { September } 1969 \\
28 \text { October } 1971 \\
\text { Nine normal non-obese controls* }\end{array}$ & $\begin{array}{r}78 \\
287 \\
97\end{array}$ & $\begin{array}{l}165 \\
403 \\
143\end{array}$ & $\begin{array}{l}309 \\
462 \\
132\end{array}$ & $\begin{array}{r}253 \\
529 \\
95\end{array}$ & $\begin{array}{r}185 \\
574 \\
84\end{array}$ & $\begin{array}{r}17 \\
6 \\
17\end{array}$ & $\begin{array}{r}305 \\
7 \\
54\end{array}$ & $\begin{array}{r}>500 \\
9 \\
83\end{array}$ & $\begin{array}{r}>500 \\
9 \\
54\end{array}$ & $\begin{array}{r}66 \\
8 \\
36\end{array}$ \\
\hline
\end{tabular}

* Mean values. 
In October 1971, she was readmitted to hospital after a short history of polyuria and polydypsia; there were no obvious precipitating factors. Urinalysis revealed heavy glycosuria and mild ketonuria.

A repeat glucose tolerance test, performed just before the institution of soluble insulin therapy, showed severe glucose intolerance accompanied, this time, by marked insulinopaenia (see Table).

The patient has been maintained on daily insulin injections ever since, with gradually increasing requirements. At present she is receiving 50 units of Lente insulin every morning. No vascular complications of the diabetes have been detected to date.

\section{COMMENT}

Our results suggest that a transient period of exaggerated insulin secretion in the patient has been succeeded by a state of beta-cell secretory failure. Correlating with this later functional abnormality is the anatomical evidence of pancreatic atrophy, with extremely reduced number of islets, described at necropsy in cases with coexistent FA and diabetes (Thoren, 1962).

Mechanisms for the initial hypersecretion of insulin are speculative. In view of the associated glucose intolerance, it is tempting to postulate that a situation of peripheral insulin resistance existed. However, none of the factors known to be associated with insulin antagonism (such as obesity, acromegaly, liver disease, or pregnancy) were present, nor was there any elevation of the basal insulin level-a characteristic feature of the disorder (Porte and Bagdade, 1970). The possibility that the raised plasma insulin levels could, in part, have been due to excessive secretion of biologically less active but immunologically similar pro-insulin (Lazarus, Penhos, Tanese, Michaels, Gutman, and Recant, 1970) cannot be discounted.

The fairly rapid progression from chemical to clinical diabetes suggests that patients with FA who have mild abnormalities of glucose tolerance should be regularly reassessed for the early detection of significant deterioration.

In conclusion, findings in this case provide a further example of the unusual disorders of carbohydrate metabolism and insulin secretion that have been described in a number of neurological and muscular diseases (British Medical Journal, 1972).

We are indebted to Mrs. R. E. Joffe for her typographical assistance, Dr. R. Zamit of the South African Institute for Medical Research for laboratory facilities, and Professor H. C. Seftel for advice and criticisms. The study was financed, in part, with grants from the South African Medical Research Council and the Witwatersrand University Council.

\section{REFERENCES}

British Medical Journal (1972). Preclinical detection of dystrophia myotonica, 21, 124-125.

Hales, C. N., and Randle, P. J. (1963). Immunoassay of insulin with insulin-antibody precipitate. Biochemical Journal, 88, 137-146.

Hewer, R. L., and Robinson, N. (1968). Diabetes mellitus in Friedreich's ataxia. Journal of Neurology, Neurosurgery, and Psychiatry, 31, 226-231.

Joffe, B. I., Segal, I., and Keller, P. (1970). Insulin levels in hereditary ataxias. New England Journal of Medicine, 283, 1410-1411.

Lazarus, N. R., Penhos, J. C., Tanese, T., Michaels, L., Gutman, R., and Recant, L. (1970). Studies on the biological activity of porcine proinsulin. Journal of Clinical Investigation, 49, 487-496.

Podolsky, S., and Sheremata, W. A. (1970). Insulin-dependent diabetes mellitus and Friedreich's ataxia in siblings. Metabolism, 19, 555-561.

Porte, D., Jr., and Bagdade, J. D. (1970). Human insulin secretion. An integrated approach. Annual Review of Medicine, 21, 219-240.

Schalch, D. S., McFarlin, D. E., and Barlow, M. H. (1970). An unusual form of diabetes mellitus in ataxia telangiectasia. New England Journal of Medicine, 282, 1396-1402.

Thoren, C. (1962). Diabetes mellitus in Friedreich's ataxia. Acta Paediatrica, 51, Supplement, 135, 239-247.

\section{ADDENDUM}

Since the preparation of this paper, six patients with Huntington's chorea have been described, with chemical diabetes and markedly elevated insulin levels in response to glucose or arginine (Podolsky, S., Leopold, N. A., and Sax, D. S. (1972). Increased frequency of diabetes mellitus in patients with Huntington's chorea. Lancet, 2, 1356-1158). Thus, the number of neurological disorders with striking abnormalities of insulin secretion is steadily increasing. 